\title{
FDI Contribution to the Maritime Industry in India
}

\author{
S. Aravindan, S. Prasad
}

\begin{abstract}
In today's economy FDI (Foreign Direct Investment) is indispensable element for economic growth of rapidly developing countries like India. The FDI in addition to providing sources of technology and best practices from the developed nations also can helps the investing companies to take benefits of cheap wages, tax benefits and other facilities from the invested countries. With respect to the shipping and ports, India allows $100 \%$ FDI and also facilitates ten years tax free for companies which develop port or container terminal, maintenance and its operations. In fact Indian government has eased the FDI in port sector through automatic route in which a foreign company doesn 't require prior approval from the central government or RBI. The automatic route is in fact now allowable in sectors and business activities. The companies can invest in shipbuilding, ship repair, ship recycling etc. This paper explains the infrastructure and economic contributions of the ports and shipping before and after the introduction FDI in these sectors. The paper describes how the FDI impacted the technological growth in the local scenario, socio economic growth of the regions, industries alongside the ports like economic zones / free zones, popularity of Indian port infrastructures in the global shipping market which will attract bigger vessels and more port calls, transshipments etc.
\end{abstract}

Keywords : FDI, RBI.

\section{INTRODUCTION}

FDIs \{Foreign direct investment\} are the capital investments obtained from individuals or corporates from a country and invest in other countries. It may be also in the form of buying major shares from an already existing business situated in the host country or starting up new business. The process of buying shares may be easier than setting up a new business due to various reasons and sometimes FDI could be done through partnerships due to local regulations. For instance, until late 2011, FDI in single brand retail was limited to $51 \%$. The FDI reforms started way back in 1991 and there was a feeling of insecurity reverberated by the liberalization policies across India. In the recent times FDI is allowed in almost all sectors from automobiles, infrastructure, telecom and defence as well. The FDI is often dubbed as a process by which the developed nation's instrument is controlling the resources and sometimes administration of developed countries. This paper starts with the discussion of history of funds inflow and showcases the FDI received in port sector in India, their

Revised Manuscript Received on September 25, 2019

* Correspondence Author

Mr.S.Aravindan, Research Scholar, Department of International Business Alagappa University Karaikudi-630004.

Dr.S.Prasad, Assistant Professor,Department of International Business Alagappa University Karaikudi-630004. impact to the development and the upcoming growth prospects. India is allowing $100 \%$ FDI in ports and shipping under automatic route and government route. As far as the ports are considered DP World, PSA International and APM Terminals are the three companies which dominate the port operations. They are biggest global terminal operators having their feet landed in many countries. It is expected that there will be more investment from other sources as well apart from the above three biggest operators in the coming years due to the massive developments in Indian economy. In an estimate, it is stated that India will need around USD 20 billion to increase the container capacity to match the country`s economic growth. Even though private is occurring in the port infrastructure but the country`s appetite is more. There are lot of initiatives from the government side like extending of 10 years tax holidays for companies engaged in developing port or terminal infrastructures, maintenance and operating business. It is said that India had received almost USD 1.64 billion between 2000 and 2019.There is project initiated by the government called National Maritime Development Programme (NMDP), which is aimed at developing the maritime sector in India with proposed of US\$ 11.8 billion.

\section{NEED FOR THE STUDY}

The study attempts to explain the short history of FDI in India and how the structural changes it undergone since its introduction, the oppositions etc. The paper also will give a highlight of the FDIs happened in the other major sectors like automobile and defence recently and its impacts. The economic model associated with the contribution of FDI to the maritime sector is evaluated by considering the amount of FDI and companies which invested in India. This study also envisage how the government policies enacted over the period attracted the foreign players to invest in India. Also the understanding of the shipping companies and the assessment of FDI in the shipping companies, inland waterway operators etc.

\section{STATEMENT OF THE PROBLEM}

Ports are of great importance because most of the country's trade are carried through ports and any lag in the technology used in the ports will have a huge impact on the revenue of the country. The negligence or the country`s failure to adopt new technology may lead to financial loss for instance if the turn round time of vessels are comparatively more than other neighboring country`s ports. 
The policy of allowing the FDI in port infrastructure perhaps will lead to implementing the latest technologies and thus enable the host country to compete in global arena. The technological advancements combined with the flow of capital investment in other integrated projects like hinterland connectivity, railway tracks etc will lead to the economic growth of the country.

\section{HISTORY OF FDI}

FDI is often considered as source of development for a country as it provides an gateway to bring capital resources and advancements. The critical part of it as a instrument adopted by the dominant countries to take control and exploit the resources in the developing countries. This arguments requires country specific research to identify how it works for a particular cases. In our context, the year 1991 played a significant revolutionary period in planning our country's future. It is actually said that the year 1993-1994 seems to have a realization on the importance of FDI. The government started showcasing the FDI's progress began during 1995-1996. At that time it was realized that the growth of India seems to be connected with the inflow of FDI.The government had took some regulatory reforms during 1998 when there was a decrease in the flow FDI. The government formed the Foreign Investment Implementation Authority (FIIA) a single point of contact for FDI investors and government when there was a second time decline during 1999-2000.This authority was empowered to give approvals. The government had released consolidated FDI policy circulars in 2016 and 2017 as well. The government had abolished the Foreign Investment Promotion Board couple of years back which in fact is responsible for processing the FDI in case of investment exceeds INR 3000 crores and used to recommend for approval to the finance ministry. After the abolition of the FIPB the process of granting approvals for FDI has been given to the concerned Administrative Ministries/Departments. The applications can be filed on the
Foreign Investment Facilitation Portal will be forwarded to the concerned Administrative Ministry for approval.

\section{TYPES OF FDI}

Horizontal FDI - The Company will do the same business as what they are doing in their home country. We can take the car companies as examples for this.

Vertical FDI - the Company used to involve in upstream or downstream business through FDI in the host countries. For instance some car companies used to have their own car dealership and some companies goes downstream investing in assets like rubber plantations for their tyres.

Conglomerate - In this type, the company used to invest in an unrelated field which are mostly done by bigger conglomerates which would like to diversify and expand their footprints globally.

\section{FDI in Different Sectors}

According to the UNCTAD`s world investment report published in 2014, India is the fourth most favored investment destination in the world.FDI in India is almost allowed in all sectors and the sectorial lists of the FDI under various routes are often updated by the government of India. According to UNCTAD report the FDI in India is USD 40 billion during the year 2017 and it grew up by $6 \%$ last year to USD 42 billion in 2018. The UNCTAD report released recently mentioned that manufacturing, communication and financial services were the top three investment recipients. The report even said that the some of the growth was the result of mergers and acquisitions. It was mainly in the retail trade and telecommunications. The Global FDI inflows continued to slide for the third consecutive year to USD 1.3 trillion in 2018 .

The below table shows the FDI in various sectors

\begin{tabular}{|l|r|l|}
\hline \multicolumn{1}{|c|}{ Sector } & \multicolumn{1}{|c|}{ FDI CAP } & \multicolumn{1}{c|}{ Approval Route } \\
\hline Automobile & $100 \%$ & Automatic \\
\hline Defence & $49 \%$ & $\begin{array}{l}\text { Government up to 100\% of local defence ventures after } \\
\text { obtaining approval }\end{array}$ \\
\hline Airports & \multicolumn{1}{|c|}{$100 \%$} & Automatic \\
\hline Banking- Private sector & $\begin{array}{l}74 \% \\
\text { (FDI+FII/FPI }\end{array}$ & $\begin{array}{l}\text { Automatic up to 49\% } \\
\text { Government beyond } 49 \%\end{array}$ \\
\hline $\begin{array}{c}\text { Banking- Public Sector subject to } \\
\text { Banking Companies Acts 1970/80. }\end{array}$ & $\begin{array}{l}\text { (FDI+FII/FPI } \\
\text { Railway Infrastructure }\end{array}$ & \begin{tabular}{l} 
Government \\
\hline Industrial Parks - new and existing
\end{tabular} \\
\hline Telecom Services & $100 \%$ & Automatic \\
\hline Space technology & $100 \%$ & Automatic \\
\hline
\end{tabular}




\begin{tabular}{|l|r|l|}
$\begin{array}{l}\text { Construction-development projects } \\
\text { (development of townships, } \\
\text { construction of residential /commercial } \\
\text { premises, roads or bridges, hotels, } \\
\text { resorts, hospitals, educational } \\
\text { institutions, recreational facilities, city } \\
\text { and regional level infrastructure, } \\
\text { townships) }\end{array}$ & $100 \%$ & Automatic \\
\hline $\begin{array}{l}\text { Single Brand product retail trading } \\
\text { Multi Brand retail trading }\end{array}$ & $100 \%$ & $\begin{array}{l}\text { Automatic up to } 49 \% \\
\text { Government beyond } 49 \%\end{array}$ \\
\hline Hospitals Sector & $51 \%$ & Government \\
\hline $\begin{array}{l}\text { Mining and Exploration of metal and } \\
\text { non-metal }\end{array}$ & $100 \%$ & Automatic \\
\hline Education & $100 \%$ & Automatic \\
\hline
\end{tabular}

\section{FDI in Port Sector}

As mentioned above Indian government allows 100\% FDI for port development projects under the automatic route. The foreign investors in port sector is as below

- AP Moller Maersk (Denmark)

- PSA Singapore (Singapore)

- Dubai Ports World (UAE)

- Hyundai Engineering and Construction Company Limited (South Korea)

- AP Moller Maersk

Port Pipavav, India`s first port in the private sector is situated on the west coast of India. Gujarat Pipavav port ltd \{GPPL got awarded with concession in 1998. APM terminals bought $12.5 \%$ shares in GPPL during 2001 and acquired controlling stocks in 2005.In the year 2010 the company got listed in the Indian stock exchanges. In 2016 the container capacity expanded to $1.35 \mathrm{mTEUs}$. The port almost handles all cargoes from bulk, liquid, roro, containers and also has storage facilities.

PSA Singapore (Singapore)

PSA the Singapore based port operator is operating terminals in Tuticorin, Chennai, Mumbai and Kolkata.PSA is a very efficient port operators in the world which handled around 81 million TEUs overall in the year 2018.It is said that they use move 220,000 containers daily. The number of container berths in various ports as below

Tuticorin Container Terminal - 1 Container Berth Chennai International Terminals - 3 Container Berths Bharat Mumbai Container Terminals - 6 Container Berths Bharat Kolkata Container Terminals - 5 Container Berths

\section{Dubai Ports World (UAE)}

DP world operates more terminals than any other company in India. It is serving in ports like Vizag, Chennai, Cochin, Nhavasheva and Mundra.

The investment from the world's leading operators have helped the major ports in India to increase the container throughputs very significantly and also attracted many associated investments in many sectors like automobiles that many of car manufacturers having their plants here in India.

\section{CONCLUSION}

The FDI inflow across various sectors showcases the advancements, socio economic progress in the country. The FDI in India is not at all limited to some particular countries but to almost half of the world countries. Mauritius always been the top FDI contributor for since 2010 which is followed by Singapore in the second place with Japan and UK changing their places on third and fourth. The introduction of FDI in port sector paved the way for the world's top port operators to establish their business, transfer their technical knowhow adopted / discovered elsewhere to be implemented here in India to enhance the efficiency and performance which is very visible from the container and other cargo statistics available in various government sites. In addition to this the country has lot of potential for development in the port sector since the government is planning to create few more ports and also development of inland waterways for both cargo and passenger traffic. The recent development like addition of passenger ships between Mumbai and Goa will definitely pave a way for port development to handle such passenger traffic and also to invest in owning / operating such vessels in the upcoming near future.

The below table shows the FDI equity inflow from 2000 to 2009 in cumulative manner and the percentage of the funds in port sector during that period. 
FDI Contribution to the Maritime Industry in India

\begin{tabular}{|l|r|r|r|}
\hline \multicolumn{2}{|c|}{ statement on Port FDI Equity Inflows \{ cumulative ) } & $\begin{array}{l}\text { \% with } \\
\text { FDI } \\
\text { Inflows }\end{array}$ \\
\hline \multicolumn{2}{|c|}{ Period } & Amount of FDI Inflows & \\
\hline & $\begin{array}{c}\text { INR in } \\
\text { Crore }\end{array}$ & $\begin{array}{c}\text { In U\$ } \\
\text { million }\end{array}$ & \\
\hline & & & \\
\hline From April 2000 to March 2010 & 6717.36 & 1635.08 & 1.29 \\
\hline From April 2000 to March 2011 & 6717.37 & 1635.08 & 1.04 \\
\hline From April 2000 to March 2012 & 6717.38 & 1635.08 & 0.87 \\
\hline From April 2000 to March 2013 & 6717.38 & 1635.08 & 0.78 \\
\hline From April 2000 to March 2014 & 6730.91 & 1635.08 & 0.69 \\
\hline From April 2000 to March 2015 & 6730.91 & 1637.3 & 0.59 \\
\hline From April 2000 to March 2016 & 6730.91 & 1637.3 & 0.5 \\
\hline From April 2000 to March 2017 & 6730.91 & 1637.3 & 0.49 \\
\hline From April 2000 to March 2018 & 6730.91 & 1637.3 & 0.43 \\
\hline From April 2000 to March 2019 & 6730.91 & 1637.3 & 0.39 \\
\hline
\end{tabular}

\section{REFERENCES}

1. India Surging Ahead 2019-Economic Diplomacy and States Division, Ministry of External Affairs.

2. UNCTAD World Investment Report 2019

3. India's Recent Inward Foreign Direct Investment An Assessment - K.S.

Chalapati Rao \& Biswajit Dhar 2018

4. www.dipp.gov.in

5. www.isid.org.in

6. www.fifp.gov.in

7. www.rbi.org.in

8. http://www.ceicdata.com

9. http://fdi.finance.com

10. www.toanewdawn.blogspot.com

11. https://www.ukibc.com 